\title{
B Chromosomes in Genus Sorghum (Poaceae)
}

\author{
Martina Bednářová, Miroslava Karafiátová, Eva Hřibová (1) and Jan Bartoš * (i)
}

check for

updates

Citation: Bednářová, M.;

Karafiátová, M.; Hřibová, E.; Bartoš, J. B Chromosomes in Genus Sorghum

(Poaceae). Plants 2021, 10, 505.

https://doi.org/10.3390/

plants10030505

Academic Editor: João Loureiro

Received: 12 February 2021

Accepted: 4 March 2021

Published: 9 March 2021

Publisher's Note: MDPI stays neutral with regard to jurisdictional claims in published maps and institutional affiliations.

Copyright: (c) 2021 by the authors. Licensee MDPI, Basel, Switzerland. This article is an open access article distributed under the terms and conditions of the Creative Commons Attribution (CC BY) license (https:/ / creativecommons.org/licenses/by/ $4.0 /)$.
Centre of the Region Haná for Biotechnological and Agricultural Research, Institute of Experimental Botany of the Czech Academy of Sciences, Šlechtitelů 31, 77900 Olomouc, Czech Republic; bednarova@ueb.cas.cz (M.B.); karafiatova@ueb.cas.cz (M.K.); hribova@ueb.cas.cz (E.H.)

* Correspondence: bartos@ueb.cas.cz

\begin{abstract}
B chromosomes (Bs) are supernumerary dispensable genomic elements that have been reported in several thousand eukaryotic species. Since their discovery, Bs have been subjected to countless studies aiming at the clarification of their origin, composition, and influence on the carriers. Despite these efforts, we still have very limited knowledge of the processes that led to the emergence of Bs, the mechanisms of their transmission, and the effects of Bs on the hosts. In the last decade, sophisticated molecular methods, including next-generation sequencing, have provided powerful tool to help answer some of these questions, but not many species have received much attention yet. In this review, we summarize the currently available information about Bs in the genus Sorghum, which has so far been on the periphery of scientific interest. We present an overview of the occurrence and characteristics of Bs in various Sorghum species, discuss the possible mechanisms involved in their maintenance and elimination, and outline hypotheses of the origin of Bs in this genus.
\end{abstract}

Keywords: B chromosomes; supernumerary chromosomes; Sorghum; chromosome elimination; phylogenesis; evolution

\section{Introduction}

B chromosomes (Bs) are supernumerary, dispensable chromosomes that have been observed in all major groups of living organisms - animals, plants, and fungi [1]. The basic characteristics of Bs are their inability to pair with A chromosomes (As) during meiosis and their irregular mode of inheritance [2,3]. As the transmission rate of Bs is higher than 0.5, they can be viewed as parasitic elements with their own evolutionary pathway [4]. One of the common features of Bs is that they are present only in some individuals of a particular species, and this variability may also exist at the level of populations or even at the level of tissues of a single individual. Most Bs share the common basic features mentioned above, but they have also developed some species-specific attributes, which in some cases resulted in the emergence of unique systems of Bs [5].

Bs are known to be present in a number of plant species, however, they have been studied in more detail mainly in plants with agronomic importance (e.g., rye, maize) [6-13]. Information about Bs in other plant species is rather superficial. In angiosperms, Bs tend to be present in species that have relatively large genomes and a small number of chromosomes [14-16]. Bs were found in 8\% monocots and 3\% eudicots, and their distribution in various orders, families, and genera is not random [17]. Among monocotyledonous plants, the orders Commelinales and Liliales seem to be the "hotspots" of B chromosome occurrence [17].

Based on the dispensable nature of Bs and on their potentially detrimental effect on a host, it would be logical to expect that they will be gradually suppressed and subsequently eradicated from the population. However, Bs seem to successfully persist in the populations thanks to their specific accumulation mechanisms [18]. One of these mechanisms is nondisjunction, which has been relatively well described in rye and maize [12,19-22]. In maize, nondisjunction takes place during the second pollen mitosis, when two sperm cells are formed. Sister chromatids of B chromosome fail to disjoin at anaphase; both are 
pulled to one pole and thus end up in one sperm cell. As a result, one of the sperm cells accumulates B chromosome at the expense of the other. The sperm cell with B chromosome then preferentially merges with the egg cell [20,23-25]. In rye, nondisjunction occurs during the first pollen mitosis, when vegetative and generative nuclei are formed: both chromatids of the B chromosome are in most cases included in the generative nucleus [26]. Nondisjunction of rye and maize Bs are both examples of post-meiotic drive. Besides this mechanism, pre-meiotic and meiotic drive have also been reported, but mainly in animals [27-30].

Generally, Bs are smaller than As, but Bs of similar size as As ("large" Bs) have also been reported [2,31,32]. In many species, different morphological variants of Bs have been observed within a single species, for example, in chives Allium schoenoprasum, grasshopper Eyprepocnemis plorans, or fish Astyanax scabripinnis [33-35]. Bs occur in different organisms at variable numbers, and the tolerable maximum depends on the particular species. When present in low numbers, Bs generally do not have any detrimental effect on the host, however, in higher numbers they can reduce the fitness of the carrier [2]. There have been a few reports suggesting some positive effects of the presence of Bs on their carrier [36-38], but in general, Bs do not provide any obvious benefits.

Due to the absence of selection pressure, Bs behave like a "genomic sponge" and accumulate sequences of various origins. As shown in rye and maize, Bs can accumulate organellar DNA, transposable elements, satellite sequences, ribosomal DNA, and other sequences from various As [39-41]. Bs can also contain genic sequences, but they are mostly not functional due to the pseudogenization [42-44]. All captured sequences can then diverge from their original homologues, and thus Bs can serve as a potential source of genetic variability. Although Bs have been considered transcriptionally inactive elements, recent studies indicate that at least some Bs are transcriptionally active and contain functional protein-coding genes [45-48]. Genes localized on Bs were shown to play a role in female sex determination in cichlid fish [49], in the processes related to cell division in E. plorans [48], and in the cell cycle and development in the red fox (Vulpes vulpes) and raccoon dog (Nyctereutes procyonoides procyonoides) [50]. These data suggest that Bs can carry genes controlling their specific behavior.

\section{B Chromosomes in the Genus Sorghum}

In the genus Sorghum, Bs have been reported in five species: S. bicolor ssp. verticilliflorum [51], S. stipoideum (Figure 1a) [52], S. purpureosericeum (Figure 1b) [53,54], S. halepense (Figure 1c) [55,56], and S. nitidum (Figure 1d) [31,57]. Despite the morphological variability of Bs described in sorghums, they share one common feature-they are well preserved in the cell lineages leading to the reproductive organs, but are absent in most somatic tissues. Several cytological studies on Sorghum Bs have been performed, and their morphology and behavior during meiosis have been relatively well documented in all species except S. bicolor ssp. verticilliflorum.

From all the Bs in genus Sorghum, the most detailed information is available about Bs from S. purpureosericeum. A maximum of six Bs in one cell was reported in this species [53], and the Bs described so far are not morphologically identical. Darlington and Thomas [54] described three types of heterochromatic Bs (long, medium, short), which did not pair with each other. Based on the published reports, the medium type of B chromosome with visible constriction seems to be the most common. The transmission of $B$ chromosome(s) through meiosis in both $1 \mathrm{~B}$ and $2 \mathrm{~B}$ plants has been well documented, showing nearly regular behavior in $2 \mathrm{~B}$ plants, resulting in four microspores with $1 \mathrm{~B}$ chromosome. In $1 \mathrm{~B}$ plants, however, the $\mathrm{B}$ chromosome passes undivided through the first meiotic division and divides in a second division, giving rise to two microspores with $1 \mathrm{~B}$ and two without [58]. Meiosis of B-carrying plants was also previously studied by D'cruz and Deshmukh [59], who found precociously dividing B chromosome at metaphase I of male meiosis. An outline of the B chromosome behavior in the first pollen mitosis was proposed by Darlington and Thomas [54], who also suggested a unique manner of the accumulation of Bs in this species. They observed extra divisions (polymitosis) between the first and 
second pollen mitosis, which they believed led to B chromosome multiplication [54]. The existence of the micronucleus containing Bs in resting cells has also been noticed, and the theory of $\mathrm{B}$ chromosome elimination via micronucleation has been previously proposed in earlier reports $[52,54,58]$.

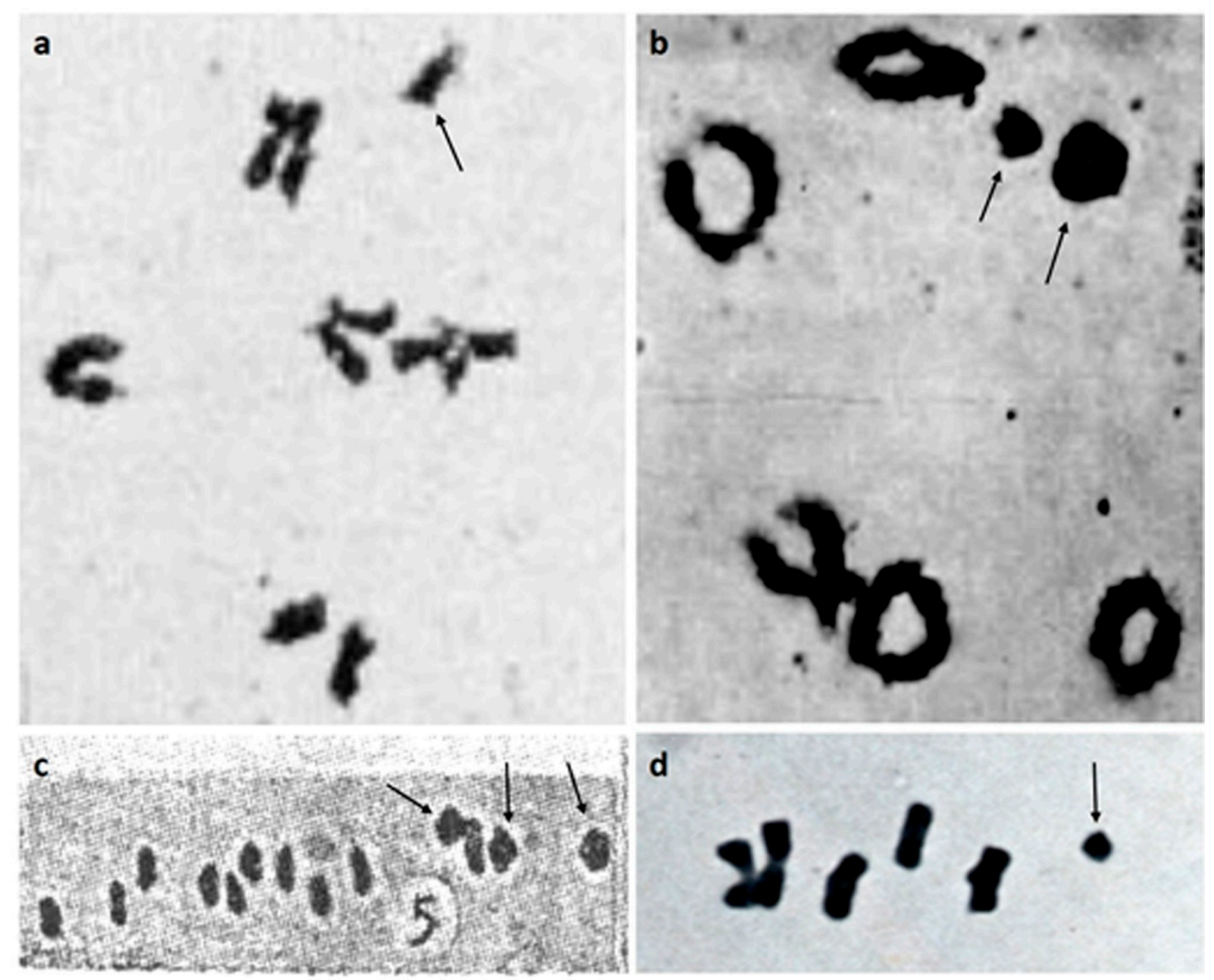

Figure 1. Chromosome pairing in meiotic metaphase I in pollen mother cells of Sorghum sp. Bs are marked by arrows. (a) Five A-bivalents and one B-univalent of S. stipoideum [52] (reprinted with permission from Springer Nature: Nature, Heredity, Bchromosomes in Sorghum stipoideum, Wu, Copyright 1992); (b) Five A-bivalents and two B-univalents in S. purpureosericeum [54] (copied from Morbid mitosis and the activity of inert chromosomes in Sorghum, Darlington and Thomas (1941) with the permission of the publisher); (c) Ten A-bivalents and three B-bivalents of S. halepense [56] (modified from Paternal transmission of accessory chromosomes in a species of Eu-sorghum, Raman et al. (1965)); (d) Five A-bivalents and one B-univalent of S. nitidum [57] (copied from Accessory chromosome in Sorghum nitidum Pers., Wu and Pi (1975) with the permission of the publisher).

In S. nitidum, Raman and Krishnaswami [31] observed Bs in diploid plants $(2 \mathrm{n}=2 \mathrm{x}=10)$, but not in tetraploids $(2 \mathrm{n}=4 \mathrm{x}=20)$. The size of Bs was equal to the chromosomes of $\mathrm{A}$ complement. When two Bs were present, they paired regularly and behaved normally at meiosis. $\mathrm{Wu}$ and $\mathrm{Pi}$ [57], and later $\mathrm{Wu}$ [60], analyzed S. nitidum plants with one B chromosome $(2 \mathrm{n}=2 \mathrm{x}=10+1 \mathrm{~B})$. They described $\mathrm{B}$ chromosome as an isochromosome, which folded back to pair with itself at the pachytene. The whole chromosome was heterochromatic with a terminal knob distal to the centromere, and its heterochromatic arm was separated from the knob by a constriction. This B chromosome was much shorter than any chromosome of the A-complement, which indicates that $S$. nitidum might contain more than one type of B chromosome.

The only study on the Bs in S. stipoideum was published by $\mathrm{Wu}$ [52]. The author found one type of B chromosome, which was distinctly shorter than any of the As and euchromatic 
along its whole length. Its euchromatic nature is interesting in the context of the fact that the other Bs in the Sorghum genus are heterochromatic, and it implies transcriptional activity. However, the euchromatic nature of Bs is not striking, as, for instance, Allium cernuum and Crepis pannonica also carry partially or completely euchromatic Bs [61,62]. The B chromosome of $S$. stipoideum was described as an isochromosome, which exhibited inter-arm pairing when present only in one copy. At anaphase I of $1 \mathrm{~B}$ plants, B chromosome divided precociously or moved undivided to one pole of the cell. During anaphase II, the majority of the cells had lagging B-chromatids and after division, micronuclei were observed, indicating $\mathrm{B}$ chromosome elimination. In 2B plants, meiotic behavior was nearly regular. However, numerical variability among and even within the spikelets was observed [52].

In S. halepense, four to six Bs have been observed, and their occurrence seems to be limited exclusively to diploids $(2 n=2 x=20)$ [63]. The behavior of Bs during meiosis in pollen mother cells was aberrant; accessory bivalents exhibited delayed disjunction or nondisjunction leading to the subsequent elimination. Three types of Bs were reported, two of which showed partial homology $[56,63]$.

The presence of B chromosome in S. bicolor ssp. verticilliflorum is rather questionable. Huskins and Smith [51] observed an additional pair of chromosome fragments during male meiosis in this species. These fragments were much smaller than As and were attached to a bivalent of As. They considered those fragments to be a pair of supernumerary chromosomes. However, as this study is the only existing work describing the presence of Bs in this species, it is questionable whether it was a real B chromosome or rather a mere chromosomal fragment. It has been documented that some chromosomes contain so-called "fragile sites" that are prone to breakage during cell division and are sensitive to replication stress [64]. In plants, these sites are associated with $45 \mathrm{~S}$ rDNA. Fragile sites can lead to chromosomal rearrangements and affect genome organization [65-67]. In the case of $S$. bicolor ssp. verticilliflorum, fragile sites in some genotypes might lead to chromosomal fragments misinterpreted as Bs. Unfortunately, so far there has been no other research that could confirm or disprove the existence of Bs in this species.

\section{Elimination and Maintenance of B Chromosomes}

Although Bs are usually transmitted regularly in mitosis, sorghums belong to species where the transmission is irregular. Bs in genus Sorghum show a high level of numerical instability, which is frequently observed in somatic tissues. In all Sorghum species, B chromosome elimination or irregular transmission leads to a mosaic distribution of the Bs. In S. purpureosericeum, Janaki-Amal [53] reported B chromosome absence in roots. Darlington and Thomas [54] described B chromosome absence in root, stem, and leaf tissues in the same species. These findings correspond with the results of a recently published study [68], in which the authors analyzed parts of adult B-carrying plants in order to identify the tissues where the B chromosome is preserved. Except for the inflorescence, where Bs are stably present, the residual population of B-carrying nuclei was detected in leaf meristem, last node, and peduncle. Thus, in S. purpureosericeum, Bs probably persist only in the meristems from which generative organs are later established, and are likely to be eliminated from other vegetative tissues [68]. Similarly, B elimination from root tissue was noticed in S. nitidum [31] and S. halepense [56]. In microsporocytes and tapetal cells of S. stipoideum, Bs occurred mosaically, while root, stem, and leaf meristem cells were completely lacking Bs [52]. Recently, the process responsible for the elimination of B chromosome from the roots of Aegilops speltoides has been described [69]. The strictly controlled process is based on B chromatid nondisjunction in mitosis, lagging in anaphase, and the formation of a micronucleus, which is subsequently eliminated. Elimination mechanisms in Sorghum have not yet been investigated, but they might be similar to Aegilops.

Research on other B-containing species indicates that the existence of accumulating mechanisms is necessary to avoid the loss of Bs [70]. The Bs in genus Sorghum also undoubtedly had to evolve some accumulation mechanism(s) acting directly against natural 
selection. However, our knowledge of these multiplicative mechanisms is only fragmentary. If we consider possible divisions where the nondisjunction can take place, the meiotic drive can be ruled out, as the division of pollen mother cells was proven to be regular [54,58]. As pre-meiotic drive is generally rare, attention should be focused mainly on pollen mitosis. A solitary study of Darlington and Thomas [54] is the only work dealing with the division following male meiosis. The authors did not find any irregularities in first pollen mitosis and suggested that nondisjunction occurs during second pollen division. Conclusions presented in this work were drawn from the statistical analysis of progenies of B-carrying plants, and the study lacks strong proof of this hypothesis. This approach, based on the analysis of the frequency and number of Bs in the offspring, can be replaced today by technologically advanced methods, which enable the visualization of the B chromosome in situ, directly on its way through both pollen mitoses. These modern approaches have already been used to elucidate the mechanism of nondisjunction in rye or Aegilops [12,71]. Markers recently developed for S. purpureosericeum [68] open up the possibility of also using these approaches in Sorghum.

The tissue-specific elimination of Bs complicates their detection in growing plants. In the sorghum model, the detection of Bs requires the cultivation of the plant up to the stage of inflorescence, when immature anthers are collected and the meiocytes are scored at metaphase I, when the presence of Bs can be determined. In species with a specific proportion of A and B chromosomes, an alternative approach based on flow cytometry can be used (Figure 2) [68]. Although the flow cytometry screening method also requires the inflorescence, it is less laborious and thus facilitates and speeds up the whole detection process. The protocol was originally established for S. purpureosericeum and worked well both for isolated haploid nuclei from pollen grains and for samples prepared from whole florets. However, this approach is not suitable for the detection of Bs in very young seedling/seeds, as it requires a relatively large amount of material and thus is destructive. The flow cytometry approach has previously been used to detect Bs in leaves and immature embryos of Aegilops speltoides [69,71]. The evaluation of B status in developing seeds would make the work significantly faster, however, unfortunately, this kind of approach based on PCR markers is not currently available.
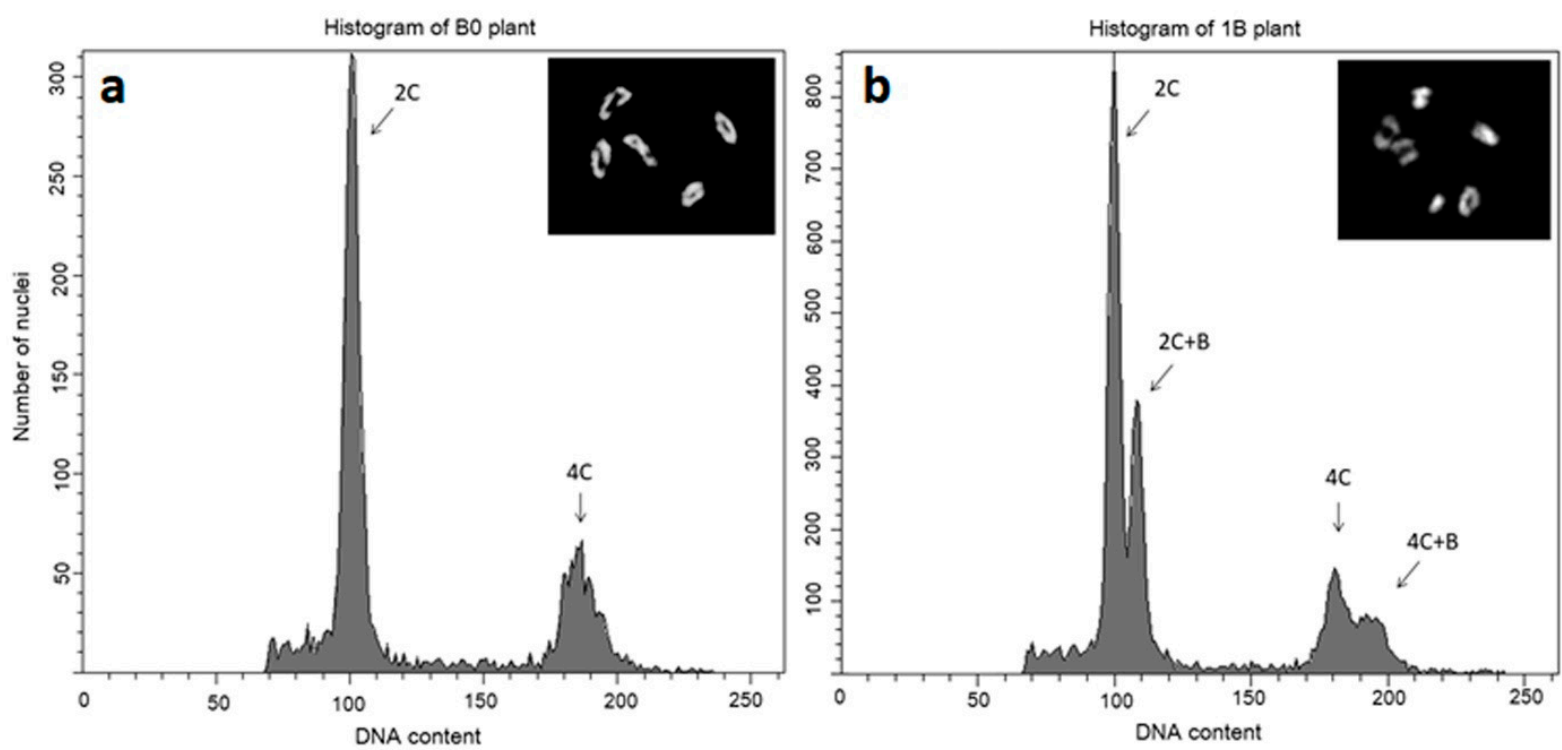

Figure 2. Flow cytometric analysis of the nuclei of Sorghum purpureosericeum isolated from spikelets. The cytological verification of B chromosome presence/absence in the analyzed plant is shown in the inset. (a) Histogram of B-negative plant showing two distinct peaks corresponding to 2C and 4C nuclei; (b) histogram of B-positive plant with a significant change in the flow karyotype. Even one copy of the B chromosome results in a clear separation of the populations of nuclei carrying $\mathrm{B}$ chromosome at both $2 \mathrm{C}$ and $4 \mathrm{C}$ ploidies. 
Cytological techniques play an irreplaceable role in B chromosome research, but only molecular studies are able to provide us with information that is above the resolution of cytogenetics. Sequencing is a powerful tool that can bring us information about the genomic content, origin, evolution, and biological role of Bs. Next-generation sequencing, enabling large-scale analysis, provides an opportunity for a significant advance in B chromosome research. However, out of the five types of Bs reported in Sorghum, only the B chromosome in S. purpureosericeum has been subjected to molecular studies so far [68]. Sequence analysis has revealed several B-specific repeats in this chromosome, including DNA transposon/hAT and one LINE element. Based on the selected repetitive sequences, PCR and cytogenetic markers specific for B chromosome have been developed [68]. The accumulation of different types of repeats in Bs is common; these repeats are often strongly amplified and may even form a significant part of the B chromosome, like the PSR element in Nasonia vitripennis [72] or micro B of Brachycome dichromosomatica [73]. B-specific repeats have also been identified in other plant species, such as E3900 and D1100 in rye [10,13], ZmBs and StarkB in maize [7,74], and Bd49 in B. dichromosomatica [75].

\section{Did B Chromosomes Emerge Several Times in the Genus Sorghum?}

Sorghum is a genus of monocot flowering plants in the grass family Poaceae, subfamily Panicoideae, and the tribe Andropogoneae. The genus includes 23 annual and perennial species and number of subspecies and races resulting from hybridization. Based on morphological traits, they are divided into five subgenera: Sorghum, Parasorghum, Stiposorghum, Chaetosorghum, and Heterosorghum (Figure 3) [76]. Subgenus Sorghum is represented by cultivated sorghum (Sorghum bicolor (L.) Moench) and its wild relatives. Representatives of this subgenus originated in Africa and Asia, and their chromosome numbers are $2 n=2 x=20$ in diploids and $2 n=4 x=40$ in tetraploids [77]. The subgenus Parasorghum includes seven species from Australia, Central America, Africa, and Asia [77], and their chromosome numbers vary from $2 \mathrm{n}=2 \mathrm{x}=10,20,30$ to 40 . S. macrospermum $(2 n=2 x=40)$ is the only representative of the subgenus Chaetosorghum and can be found endemically in the Northern Territory of Australia. Subgenus Heterosorghum is represented by S. laxiflorum, growing in Northern Australia and Papua New Guinea $(2 n=2 x=40)$. The last subgenus, Stiposorghum, includes 10 species occurring in Northern Australia with chromosome numbers ranging from $2 n=2 x=10,20,30$ to 40 [77].

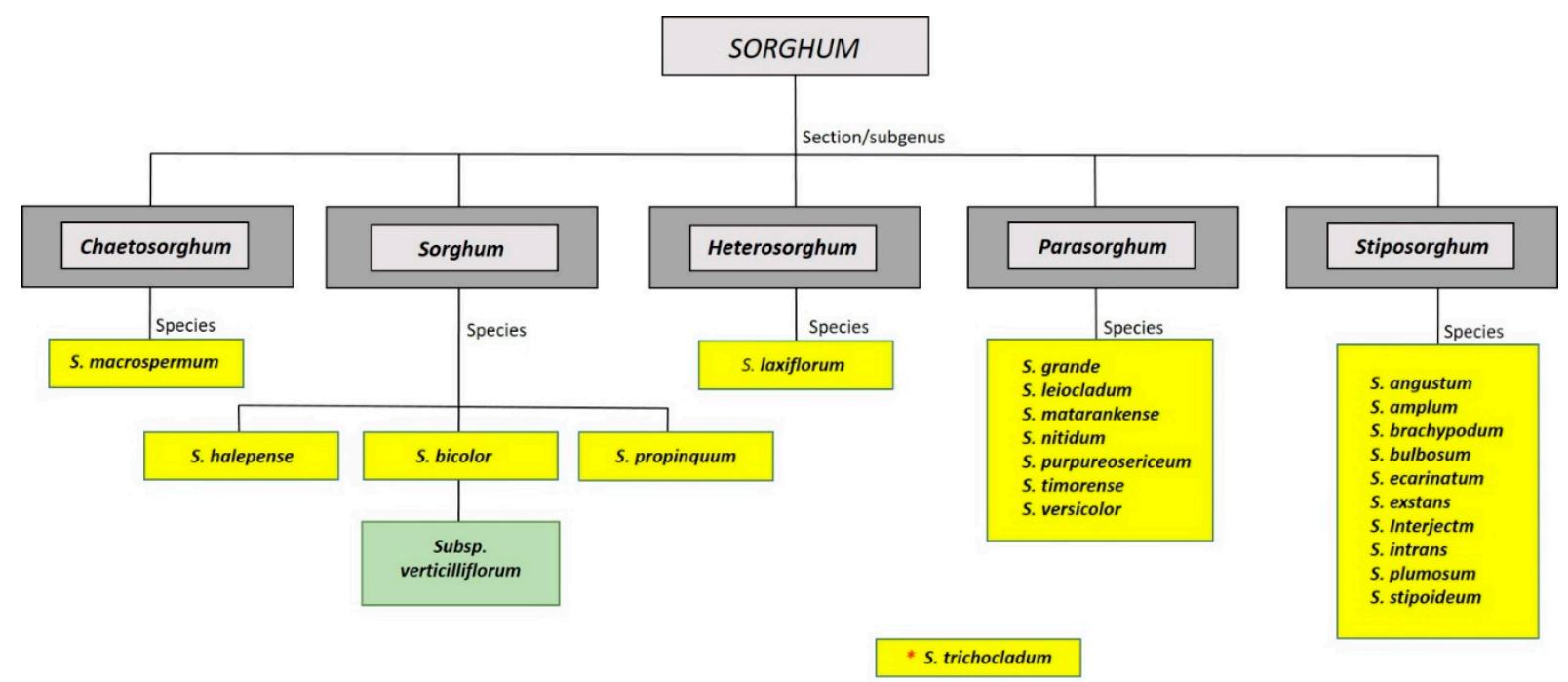

Figure 3. Classification of Sorghum (modified from Ananda et al. [78]) * S. trichocladum has not yet been assigned to any subgenus.

The genus Sorghum has been subjected to several phylogenetic analyses [79-82], most of which agree with this classification of species into the abovementioned sections, although relationships between some sister taxa are still under debate. For example, a 
close relationship between S. macrospermum and S. laxiflorum led to proposals to merge the Chaetosorghum and Heterosorghum sections [80-82]. We have performed phylogenetic reconstruction of the genus with a focus on species possessing Bs. PhyML analysis of concatenated sequences of ITS1-ITS2, trnH-psbA, and trnL-trnF resulted in a phylogram in which two strongly supported major clades I and II were identified (Figure 4), which is in agreement with the phylogenetic analyses published previously.

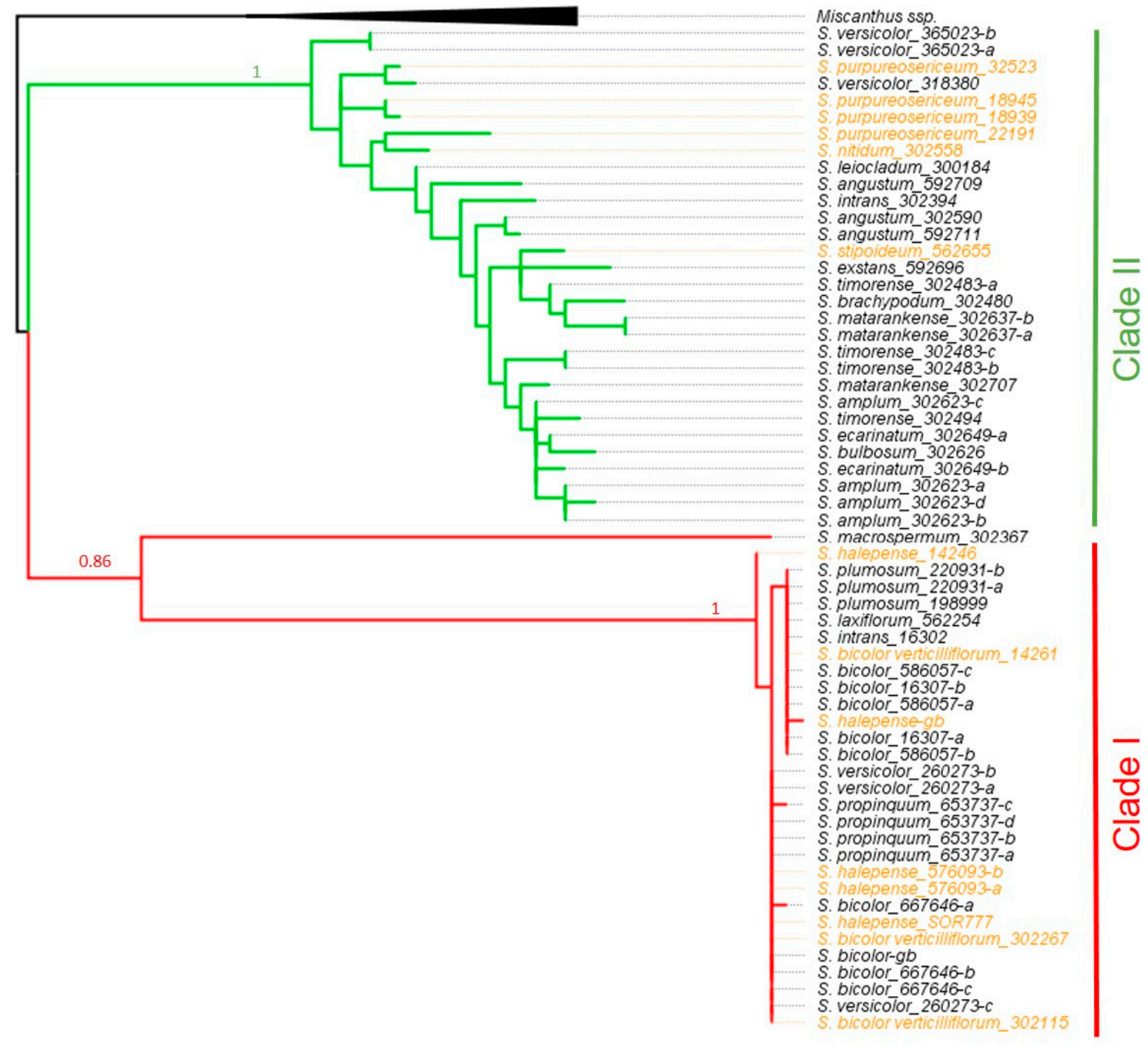

0.003

Figure 4. Phylogenetic tree of 21 Sorghum species based on phyML analysis using concatenated nuclear and chloroplastic sequences (ITS1-ITS2-trnHpsbA-trnLtrnF). With strong branch support, two main clades I and II are resolved. B-carrying species are marked in orange.

A widely accepted hypothesis of the formation of Bs assumes that they have autosomal origin. This is supported by the fact that sequences similar to those from As have often been found on Bs. Bs containing mosaically organized sequences derived from different As have been described, for example, in rye [39], maize [83], and Brachycome dichromosomatica [73]. In Nasonia vitripennis, B chromosome was formed from interspecies hybridization [84]. Additionally, Bs originating from sex chromosomes were described in grasshopper Eyprepocnemis plorans and frog Leiopelma hochstetteri [85,86]. Despite countless studies dealing with the possible origin and evolution of B chromosome(s) $[7,39,84,87-90]$, these issues still remain unclear. 
There are three possible evolutionary scenarios for B chromosome(s) in the genus Sorghum (Figure 5). B chromosome(s) may have formed (1) in a single event in a common ancestor of all Sorghum species and then have been preserved in some lines during evolution and disappeared in others (Figure 5a); (2) once in the ancestor of closely related species, all of which have kept Bs up until today (Figure 5b); or (3) several times during independent events in Sorghum evolution, which includes also the possibility that the B chromosome originated only at the level of individual species (Figure 5c).
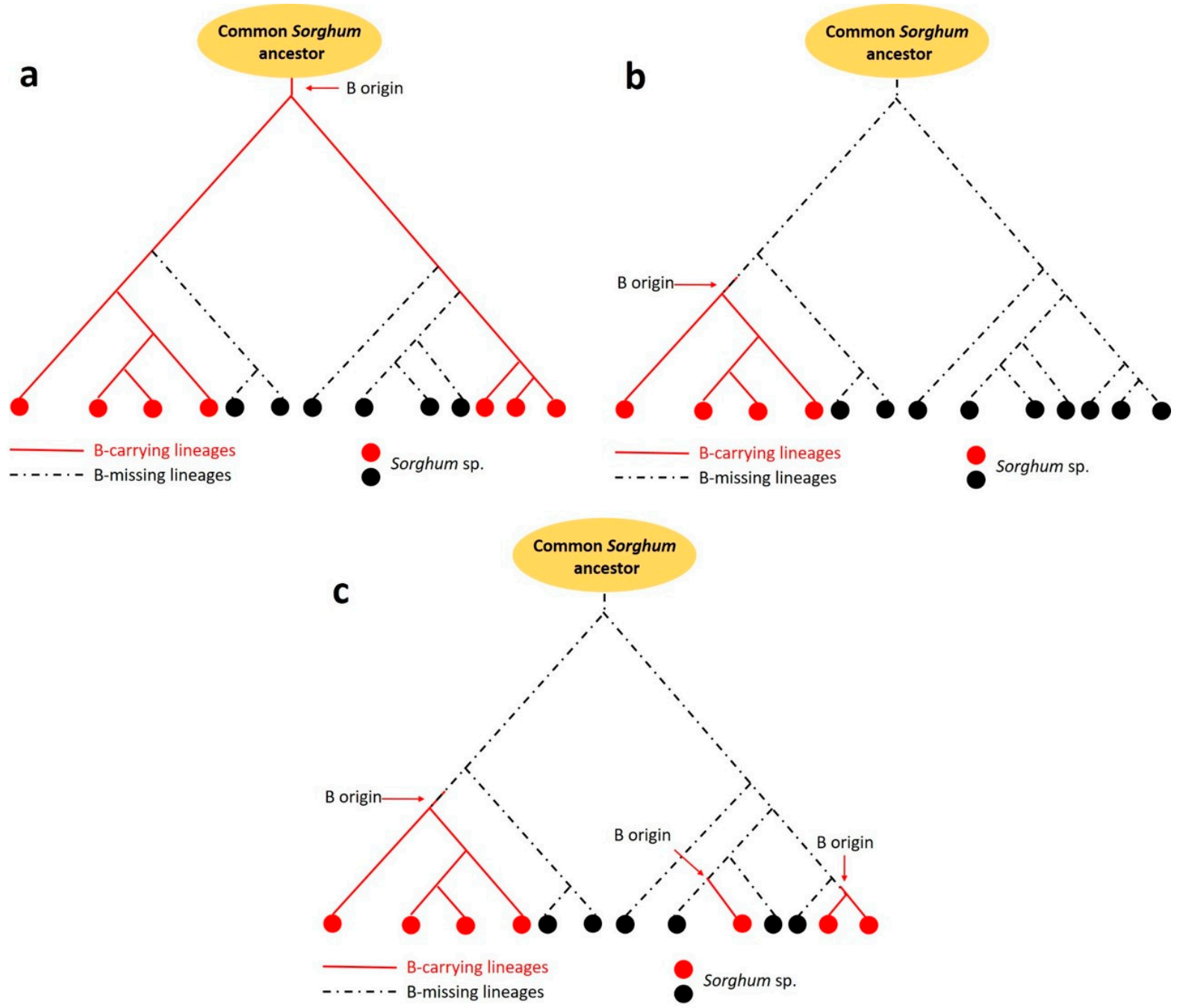

Figure 5. Schemes of the possible origin of B chromosome in the genus Sorghum. (a) Origin of B chromosome(s) in a common ancestor; (b) origin of B chromosome(s) in a group of closely related species; (c) multiple origins of B chromosome(s).

Considering the conclusions of the cytological studies [31,51-60,63], it is clear that there are several types of Bs within the genus, which differ in their morphology. One evolutionary scenario assumes the formation of the B chromosome in a single event and its persistence in closely related species. Given that Bs occur in both clades (Figure 4), we can exclude a close phylogenetic relationship between the species carrying Bs. However, the phylogenetic analysis cannot rule out the possibility that B chromosome originated only once during the early evolution of Sorghum or in the ancestor of the genus. This hypothesis could be supported or questioned based on the analysis of sequence similarity between the Bs from different species in the genus Sorghum, however, these data are not currently available. Recently, Wu et al. [71] identified B-specific tandem repeat shared by Bs in Aegilops speltoides, Aegilops mutica, and Secale cereale, however, they were not able to 
conclude whether the chromosomes have a common origin or whether the shared repetitive sequence is a result of the exchange of genetic material among those species.

The hypothesis assuming multiple independent origins of Bs in the genus Sorghum is also feasible. This scenario of $B$ chromosome origin appears to be supported by the nature of the B chromosome of S. nitidum-the appearance of B in this species might represent an example of the formation of the B chromosome at the species level, as has already been hypothesized by $\mathrm{Wu}$ and $\mathrm{Pi}[57]$ and $\mathrm{Wu}$ [60]. The $\mathrm{B}$ chromosome in S. nitidum is an isochromosome, and its arms strikingly resemble the short arm of the nucleolus-associated chromosome, which is also entirely heterochromatic and approximately similar in length. Since B chromosome does not pair with the nucleolus-associated chromosome, further structural and genic changes had to occur later, leading to the loss of homology and to the inability of $\mathrm{B}$ chromosome to pair with the short arm of the nucleolus-associated chromosome [60]. Such resemblance between Bs and As has not been found in any other Sorghum species. However, since Bs are expected to be prone to aberrations and the accumulation of mutations [11,91], a relatively rapid diversification and loss of ability to pair with the original A homologue can be assumed. It is possible that the B chromosome of S. nitidum is evolutionarily younger than other Sorghum Bs, and therefore a high level of similarity between A and B is still maintained in this species.

Another argument speaking for the independent origin of Bs in different Sorghum species is the possibility of intra- and inter-specific hybridization. It has been suggested that if hybridization occurs between separated, diverged subpopulations, various irregularities in meiosis may appear, which is a precondition for the B chromosome formation [60]. Namely, the subgenus Sorghum is a complex group that includes a number of closely related species, subspecies, and races that can interbreed freely, and some species (e.g., S. halepense) are assumed to have hybrid origin [92-94]. Frequent hybridization might represent conditions favorable for the formation of Bs. The origin of Bs through interspecific hybridization has been demonstrated in hybrid derivatives from spontaneous crossing between two Coix species [95] and has also been described in Poecilia formosa and Nasonia vitripennis [84,96,97].

\section{Conclusions}

$\mathrm{B}$ chromosomes (Bs) are unique genomic elements with a transmission rate higher than 0.5. Although our knowledge of Bs has advanced considerably since their discovery in the first half of the last century, many questions remain unanswered. The elusiveness of Sorghum Bs, resulting from their extensive elimination during early plant development, certainly contributed to the fact that they have not yet been subjected to any comprehensive research. In the last century, several authors have provided cytological characteristics of Bs in some Sorghum species, but since then the research in this field has hardly progressed. However, new technologies give us new opportunities to meet this challenge. The use of flow cytometric screening and sorting makes it easier to detect the presence of Bs and to obtain material for sequencing, which will be necessary for their thorough molecular characterization. So far, our knowledge of the mechanisms of accumulation or somatic elimination of Bs in Sorghum is only marginal. Analysis of the effects of Sorghum Bs on gene expression is another interesting topic that deserves thorough investigation. Research on Bs in Sorghum is still in its infancy, and there is a long way to go before we discover at least some of the mechanisms behind the unique behavior of these enigmatic elements in this genus.

Author Contributions: M.B., M.K., E.H. and J.B. wrote the manuscript. All authors have read and agreed to the published version of the manuscript.

Funding: This research was funded by the Czech Science Foundation (grant award no. 18-12338Y) and the European Regional Development Fund project "Plants as a tool for sustainable global development" (no. CZ.02.1.01/0.0/0.0/16_019/0000827).

Institutional Review Board Statement: Not applicable.

Informed Consent Statement: Not applicable. 


\section{Data Availability Statement: Not applicable.}

Acknowledgments: This work was supported by the Czech Science Foundation (grant award no. 18-12338Y) and the European Regional Development Fund project "Plants as a tool for sustainable global development" (no. CZ.02.1.01/0.0/0.0/16_019/0000827). We thank the Australian Grains Genebank, the United States Department of Agriculture and International Crops Research Institute for the Semi-Arid Tropics for providing seed stocks, and the publisher Royal Society for permission to reprint Figure 1b. Further, we thank our colleague Iva Ilíková for language editing of the manuscript.

Conflicts of Interest: All authors declare no conflict of interest.

\section{References}

1. D'Ambrosio, U.; Alonso-Lifante, M.P.; Barros, K.; Kovařík, A.; Mas de Xaxars, G.; Garcia, S. B-chrom: A database on Bchromosomes of plants, animals and fungi. New Phytol. 2017, 216, 635-642. [CrossRef]

2. Jones, R.N. B chromosomes in plants. New Phytol. 1995, 131, 411-434. [CrossRef]

3. Camacho, J.P.M.; Sharbel, T.F.; Baukeboom, L.W. B-chromosome evolution. Phil. Trans. R. Soc. Lond. B 2000, 355, 163-178. [CrossRef] [PubMed]

4. Baukeboom, L.W. Bewildering Bs: An impression of the 1st B-chromosome conference. Heredity 1994, 73, 328-336. [CrossRef]

5. Werren, J.H.; Stouthamer, R. PSR (paternal sex ratio) chromosomes: The ultimate selfish genetic elements. Genetica 2003, 117, 85-101. [CrossRef] [PubMed]

6. Carlson, W.R. A procedure for localizing genetic factors controlling mitotic nondisjunction in the B chromosome of maize. Chromosoma 1973, 42, 127-136. [CrossRef]

7. Alfenito, M.R.; Birchler, J.A. Molecular characterization of a maize B chromosome centric sequence. Genetics 1993, 135, 589-597. [CrossRef] [PubMed]

8. Stark, E.A.; Connerton, I.; Bennet, S.T.; Barnes, S.R.; Parker, J.S.; Forster, J.W. Molecular analysis of the structure of the maize B-chromosome. Chromosome Res. 1996, 4, 15-23. [CrossRef] [PubMed]

9. Jin, W.; Lamb, J.C.; Vega, J.M.; Dawe, R.K.; Birchler, J.A.; Jiang, J. Molecular and functional dissection of the maize B chromosome centromere. Plant Cell 2005, 17, 1412-1423. [CrossRef] [PubMed]

10. Sandery, M.J.; Forster, J.W.; Blunden, R.; Jones, R.N. Identification of a family of repeated sequences on the rye B chromosome. Genome 1990, 33, 908-913. [CrossRef]

11. Klemme, S.; Banaei-Moghaddam, A.M.; Macas, J.; Wicker, T.; Novák, P.; Houben, A. High-copy sequences reveal distinct evolution of the rye B chromosome. New Phytol. 2013, 199, 550-558. [CrossRef] [PubMed]

12. Banaei-Moghaddam, A.M.; Schubert, V.; Kumke, K.; Wei, O.; Klemme, S.; Nagaki, K.; Macas, J.; González-Sánchez, M.; Heredia, V.; Gómez-Revilla, D.; et al. Nondisjunction in favor of a chromosome: The mechanism of rye B chromosome drive during pollen mitosis. Plant Cell 2012, 24, 4124-4134. [CrossRef]

13. Blunden, R.; Wilkes, T.J.; Forster, J.W.; Jimenez, M.M.; Sandery, M.J.; Karp, A.; Jones, R.N. Identification of the E3900 family, a second family of rye B chromosome specific repeated sequences. Genome 1993, 36, 706-711. [CrossRef] [PubMed]

14. Vinogradov, A.E. Mirrored genome size distributions in monocot and eudicot plants. Acta Biotheor. 2001, 49, 43-51. [CrossRef]

15. Trivers, R.; Burt, A.; Palestis, B.G. B chromosomes and genome size in flowering plants. Genome 2004, 47, 1-8. [CrossRef] [PubMed]

16. Palestis, B.G.; Trivers, R.; Burt, A.; Jones, R.N. The distribution of B chromosomes across species. Cytogenet. Genome Res. 2004, 106, 151-158. [CrossRef]

17. Levin, D.A.; Palestis, B.G.; Jones, R.N.; Trivers, R. Phyletic hotspots for B chromosomes in angiosperms. Evolution 2005, 59, 962-969. [CrossRef] [PubMed]

18. Jones, R.N. B-Chromosome Drive. Am. Nat. 1991, 137, 430-442. [CrossRef]

19. Müntzing, A. Cytological studies of extra fragment chromosomes in rye; the mechanism of non-disjunction at the pollen mitosis. Hereditas 1946, 32, 97-119. [CrossRef]

20. Roman, H. Mitotic nondisjunction in the case of interchanges involving the B-type chromosome in maize. Genetics 1947, 32, 391-409.

21. Carlson, W.R.; Chou, T.S. B chromosome nondisjunction in corn: Control by factors near the centromere. Genetics 1981, 97, 379-389.

22. Han, F.; Lamb, J.C.; Yu, W.; Gao, Z.; Birchler, J.A. Centromere function and nondisjunction are independent components of the maize B chromosome accumulation mechanism. Plant Cell 2007, 19, 524-533. [CrossRef]

23. Roman, H. Directed fertilization in maize. Proc. Natl. Acad. Sci. USA 1948, 34, 36-42. [CrossRef]

24. Carlson, W.R. Factors affecting preferential fertilization in maize. Genetics 1969, 62, 543-554. [CrossRef] [PubMed]

25. Rusche, M.L.; Mogensen, H.L.; Shi, L.; Keim, P.; Rougier, M.; Chaboud, A.; Dumas, C. B chromosome behavior in maize pollen as determined by a molecular probe. Genetics 1997, 147, 1915-1921. [CrossRef] [PubMed]

26. Hasegawa, N. A cytological study on 8-chromosome rye. Cytologia 1934, 6, 68-77. [CrossRef]

27. Nur, U. A mitotically unstable supernumerary chromosome with an accumulation mechanism in a grasshopper. Chromosoma 1963, 14, 407-422. [CrossRef] [PubMed]

28. Kayano, H. Accumulation of B chromosomes in the germ line of Locusta migratoria. Heredity 1971, 27, 119-123. [CrossRef] 
29. Kayano, H. Cytogenetic studies in Lilium callosum. III. Preferential segregation of a supernumerary chromosome in EMCs. Proc. Jpn. Acad. 1957, 33, 553-558. [CrossRef]

30. Nur, U. A supernumerary chromosome with an accumulation mechanism in the lecanoid genetic system. Chromosoma 1962, 13, $249-271$. [CrossRef]

31. Raman, V.S.; Krishnaswami, D. Accessory chromosomes in sorghum nitidum Pers. J. Indian Bot. Soc. 1960, 39, $278-280$.

32. Zuk, J. The additional heterochromatic chromosome and its influence on sex chromosome pairing in Rumex. Heredity 1969, $24,69-74$. [CrossRef]

33. Holmes, D.S.; Bougourd, S.M. B-chromosome selection in Allium schoenoprasum II. Experimental populations. Heredity 1991, 67, 117-122. [CrossRef]

34. Bakkali, M.; Cabrero, J.; López-León, M. The B chromosome polymorphism of the grasshopper Eyprepocnemis plorans in North Africa. I. B variants and frequency. Heredity 1999, 83, 428-434. [CrossRef] [PubMed]

35. De Marco Ferro, D.A.; Moreira-Filho, O.; Bertollo, L.A.C. B chromosome polymorphism in the fish, Astyanax scabripinnis. Genetica 2003, 119, 147-153. [CrossRef]

36. Plowman, A.; Bougourd, S. Selectively advantageous effects of B chromosomes on germination behaviour in Allium schoenoprasum L. Heredity 1994, 72, 587-593. [CrossRef]

37. Dherawattana, A.; Sadanaga, K. Cytogenetics of a crown rust-resistant hexaploid oat with $42+2$ fragment chromosomes 1 . Crop Sci. 1973, 13, 591-594. [CrossRef]

38. Han, Y.; Liu, X.; Benny, U.; Kistler, H.C.; VanEtten, H.D. Genes determining pathogenicity to pea are clustered on a supernumerary chromosome in the fungal plant pathogen Nectria haematococca. Plant J. 2001, 25, 305-314. [CrossRef]

39. Martis, M.M.; Klemme, S.; Banaei-Moghaddam, A.M.; Blattner, F.R.; Macas, J.; Schmutzer, T.; Scholz, U.; Gundlach, H.; Wicker, T.; Simkova, H.; et al. Selfish supernumerary chromosome reveals its origin as a mosaic of host genome and organellar sequences. Proc. Natl. Acad. Sci. USA 2012, 109, 13343-13346. [CrossRef]

40. Page, B.T.; Wanous, M.K.; Birchler, J.A. Characterization of a maize chromosome 4 centromeric sequence: Evidence for an evolutionary relationship with the B chromosome centromere. Genetics 2001, 159, 291-302.

41. Cheng, Y.M.; Lin, B.Y. Cloning and characterization of maize B chromosome sequences derived from microdissection. Genetics 2003, 164, 299-310. [PubMed]

42. Banaei-Moghaddam, A.M.; Meier, K.; Karimi-Ashtiyani, R.; Houben, A. Formation and expression of pseudogenes on the B chromosome of rye. Plant Cell 2013, 25, 2536-2544. [CrossRef] [PubMed]

43. Houben, A.; Banaei-Moghaddam, A.M.; Klemme, S.; Timmis, J.N. Evolution and biology of supernumerary B chromosomes. Cell. Mol. Life Sci. 2014, 71, 467-478. [CrossRef]

44. Makunin, A.I.; Kichigin, I.G.; Larkin, D.M.; O’Brien, P.C.; Ferguson-Smith, M.A.; Yang, F.; Proskuryakova, A.A.; Vorobieva, N.V.; Chernyaeva, E.N.; O'Brien, S.J.; et al. Contrasting origin of B chromosomes in two cervids (Siberian roe deer and grey brocket deer) unravelled by chromosome-specific DNA sequencing. BMC Genom. 2016, 17, 618. [CrossRef]

45. Miao, V.P.; Covert, S.F.; Van Etten, H.D. A fungal gene for antibiotic resistance on a dispensable ("B") chromosome. Science 1991, 254, 1773-1776. [CrossRef] [PubMed]

46. Valente, G.T.; Conte, M.A.; Fantinatti, B.E.A.; Cabral-de-Mello, D.C.; Carvalho, R.F.; Vicari, M.R.; Kocher, T.D.; Martins, C. Origin and evolution of $\mathrm{B}$ chromosomes in the cichlid fish Astatotilapia latifasciata based on integrated genomic analyses. Mol. Biol. Evol. 2014, 31, 2061-2072. [CrossRef] [PubMed]

47. Ma, W.; Gabriel, T.S.; Martis, M.M.; Gursinsky, T.; Schubert, V.; Vrána, J.; Doležel, J.; Grundlach, H.; Altschmied, L.; Scholz, U.; et al. Rye B chromosomes encode a functional Argonaute-like protein with in vitro slicer activities similar to its A chromosome paralog. New Phytol. 2017, 213, 916-928. [CrossRef] [PubMed]

48. Navarro-Domínguez, B.; Ruiz-Ruano, F.; Cabrero, J.; Corral, J.M.; López-León, M.D.; Sharbel, T.F.; Camacho, J.P.M. Protein-coding genes in B chromosomes of the grasshopper Eyprepocnemis plorans. Sci. Rep. 2017, 7, 45200.

49. Yoshida, K.; Terai, Y.; Mizoiri, S.; Aibara, M.; Nishihara, H.; Watanabe, M.; Kuroiwa, A.; Hirai, H.; Hirai, Y.; Matsuda, Y.; et al. B chromosomes have a functional effect on female sex determination in Lake Victoria cichlid fishes. PLoS Genet. 2011, 7, e100220. [CrossRef]

50. Makunin, A.I.; Romanenko, S.A.; Beklemisheva, V.R.; Perelman, P.L.; Druzhkova, A.S.; Petrova, K.O.; Prokopov, D.Y.; Chernyaeva, E.N.; Johnson, J.L.; Kukekova, A.V.; et al. Sequencing of supernumerary chromosomes of red fox and raccoon dog confirms a non-random gene acquisition by B chromosomes. Genes 2018, 9, 405. [CrossRef]

51. Huskins, C.L.; Smith, S.G. A cytological study of the genus Sorghum PERS. II. The meiotic chromosomes. J. Genet. 1934, $28,387-395$. [CrossRef]

52. Wu, T. B-chromosomes in Sorghum stipoideum. Heredity 1992, 68, 457-463. [CrossRef]

53. Janaki-Ammal, E. Chromosome Diminution in a Plant. Nature 1940, 146, 839-840. [CrossRef]

54. Darlington, C.D.; Thomas, P.T. Morbid mitosis and the activity of inert chromosomes in sorghum. Proc. R. Soc. Lond. B 1941, 130, 127-150.

55. Raman, V.S.; Meenakshi, K.; Thangam, M.S.; Sivagnanam, L. The cytological behaviour of B-chromosomes in Sorghum halepense. Abst. Madras Agric. J. 1964, 51, 72-73.

56. Raman, V.S.; Thangam, M.S. Paternal transmission of accessory chromosomes in a species of Eu-Sorghum. Sci. Cult. 1965, 31, 150-151.

57. Wu, T.P.; Pi, C.P. Accessory chromosome in Sorghum nitidum Pers. Taiwania 1975, 20, 147-161.

58. Wu, T.P. B chromosomes in Sorghum purpureo-sericeum. Proc. Natl. Sci. Counc. B 1984, 8, 198-209. 
59. D'cruz, R.; Deshmukh, J.N. Behaviour of B chromosomes in Sorghum purpureosericeum. Poona Agric. Col. Mag. 1960, 51, 30-34.

60. Wu, T.P. Pachytene morphology of Sorghum nitidum chromosome complement. Cytologia 1978, 43, 433-440. [CrossRef]

61. Friebe, B. Nucleolar activity of B-chromosomes in Allium cernuum (Alliaceae). Plant Syst. Evol. 1989, 163, 87-92. [CrossRef]

62. Fröst, S.; Östergren, G. Crepis pannonica and Crepis conyzaefolia-Two more species having accessory chromosomes. Hereditas 1959, 45, 211-214. [CrossRef]

63. Raman, V.S.; Meenakshi, K.; Thangam, M.S. Accessory chromosomes and their meiotic behaviour in hybrids of grain sorghum and Johnson grass. Cytologia 1976, 41, 193-200. [CrossRef]

64. Durkin, S.G.; Glover, T.W. Chromosome fragile sites. Annu. Rev. Genet. 2007, 41, 169-192. [CrossRef] [PubMed]

65. Huang, J.; Ma, L.; Yang, F.; Fei, S.; Li, L. 45S rDNA regions are chromosome fragile sites expressed as gaps in vitro on metaphase chromosomes of root-tip meristematic cells in Lolium spp. PLoS ONE 2008, 3, e2167. [CrossRef] [PubMed]

66. Bustamante, F.O.; Rocha, L.C.; Torres, G.A.; Davide, L.C.; Mittelmann, A.; Techio, V.H. Distribution of rDNA in diploid and polyploid Lolium multiflorum Lam. and fragile sites in 45S rDNA regions. Crop Sci. 2014, 54, 617-625. [CrossRef]

67. Lan, H.; Chen, C.L.; Miao, Y.; Yu, C.X.; Guo, W.W.; Xu, Q.; Deng, X.X. Fragile sites of 'Valencia' sweet orange (Citrus sinensis) chromosomes are related with active 45s rDNA. PLOS ONE 2016, 11, e0151512. [CrossRef]

68. Karafiátová, M.; Bednářová, M.; Said, M.; Čížková, J.; Holušová, K.; Blavet, N.; Bartoš, J. B chromosome of Sorghum purpureosericeum reveals the first pieces of its sequence. J. Exp. Bot. 2020, 72, 1606-1616. [CrossRef]

69. Ruban, A.; Schmutzer, T.; Wu, D.D.; Fuchs, J.; Boudichevskaia, A.; Rubtsova, M.; Pistrick, K.; Melzer, M.; Himmelbach, A.; Schubert, V.; et al. Supernumerary B chromosomes of Aegilops speltoides undergo precise elimination in roots early in embryo development. Nat. Commun. 2020, 11, 2764. [CrossRef]

70. Jones, R.N.; Gonzáles-Sanchez, M.; González-García, M.; Vega, J.M.; Puertas, M.J. Chromosome with their life of their own. Cytogenet. Genome Res. 2008, 120, 265-280. [CrossRef]

71. Wu, D.; Ruban, A.; Fuchs, J.; Macas, J.; Novák, P.; Vaio, M.; Zhou, Y.; Houben, A. Nondisjunction and unequal spindle organization accompany the drive of Aegilops speltoides B chromosomes. New Phytol. 2019, 223, 1340-1352. [CrossRef]

72. Eickbush, D.G.; Eickbush, T.H.; Werren, J.H. Molecular characterization of repetitive DNA sequences from a B chromosome. Chromosoma 1991, 101, 575-583. [CrossRef] [PubMed]

73. Houben, A.; Verlin, D.; Leach, C.R.; Timmis, J.N. The genomic complexity of micro B chromosomes of Brachycome dichromosomatica. Chromosoma 2001, 110, 451-459. [CrossRef] [PubMed]

74. Lamb, J.C.; Meyer, J.M.; Corcoran, B.; Kato, A.; Han, F.; Birchler, J.A. Distinct chromosomal distributions of highly repetitive sequences in maize. Chromosome Res. 2007, 15, 33-49. [CrossRef] [PubMed]

75. Franks, T.K.; Houben, A.; Leach, C.R.; Timmis, J.N. The molecular organisation of a B chromosome tandem repeat sequence from Brachycome dichromosomatica. Chromosoma 1996, 105, 223-230. [CrossRef] [PubMed]

76. Garber, E.D. Cytotaxonomic studies in the genus Sorghum. Univ. Calif. Publ. Bot. 1950, 23, $283-361$.

77. Lazarides, M.; Hacker, J.B.; Andrew, M.H. Taxonomy, cytology and ecology of indigenous Australian sorghums (Sorghum Moench: Andropogoneae: Poaceae). Aust. Syst. Bot. 1991, 4, 591-635. [CrossRef]

78. Ananda, G.; Myrans, H.; Norton, S.L.; Gleadow, R.; Furtado, A.; Henry, R.J. Wild Sorghum as a promising resource for crop improvement. Front. Plant Sci. 2020, 11, 1108. [CrossRef]

79. Sun, Y.; Skinner, D.Z.; Liang, G.H.; Hulbert, S.H. Phylogenetic analysis of Sorghum and related taxa using internal transcribed spacers of nuclear ribosomal DNA. Theor. Appl. Genetics 1994, 89, 26-32. [CrossRef]

80. Ng'uni, D.; Geleta, M.; Fatih, M.; Bryngelsson, T. Phylogenetic analysis of the genus Sorghum based on combined sequence data from cpDNA regions and ITS generate well-supported trees with two major lineages. Ann. Bot. 2010, 105, 471-480. [CrossRef] [PubMed]

81. Liu, Q.; Liu, H.; Wen, J.; Peterson, P.M. Infrageneric phylogeny and temporal divergence of Sorghum (Andropogoneae, Poaceae) based on low-copy nuclear and plastid sequences. PLOS ONE 2014, 9, e104933. [CrossRef]

82. Hawkins, J.S.; Ramachandran, D.; Henderson, A.; Freeman, J.; Carlise, M.; Harris, A.; Willison-Headley, Z. Phylogenetic reconstruction using four low-copy nuclear loci strongly supports a polyphyletic origin of the genus Sorghum. Ann. Bot. 2015, 116, 291-299. [CrossRef] [PubMed]

83. Peng, S.F.; Lin, Y.P.; Lin, B.Y. Characterization of AFLP sequences from regions of maize B chromosome defined by 12 B-10L translocations. Genetics 2005, 169, 375-388. [CrossRef]

84. McAllister, B.F.; Werren, J.H. Hybrid origin of a B chromosome (PSR) in the parasitic wasp Nasonia vitripennis. Chromosoma 1997, 106, 243-253. [CrossRef] [PubMed]

85. López-León, M.D.; Neves, N.; Schwarzacher, T.; Heslop-Harrison, J.S.; Hewitt, G.M.; Camacho, J.P.M. Possible origin of a B chromosome deduced from its DNA composition using double FISH technique. Chromosome Res. 1994, 2, 87-92. [CrossRef]

86. Sharbel, T.F.; Green, D.M.; Houben, A. B-chromosome origin in the endemic New Zealand frog Leiopelma hochstetteri through sex chromosome devolution. Genome 1998, 41, 14-22. [CrossRef]

87. Donald, T.; Leach, C.; Clough, A.; Timmis, J.N. Ribosomal RNA genes and the B chromosome of Brachycome dichromosomatica. Heredity 1995, 74, 556-561. [CrossRef] [PubMed]

88. Jamilena, M.; Garrido-Ramos, M.; Rejón, M.R.; Rejón, C.R.; Parker, J.S. Characterization of repeated sequences from microdissected B chromosomes of Crepis capillaris. Chromosoma 1995, 104, 113-120. [CrossRef] 
89. Dhar, M.K.; Friebe, B.; Koul, A.K.; Gill, B.S. Origin of an apparent B chromosome by mutation, chromosome fragmentation and specific DNA sequence amplification. Chromosoma 2002, 111, 332-340. [CrossRef]

90. Fantinatti, B.E.; Mazzuchelli, J.; Valente, G.T.; Cabral-de-Mello, D.C.; Martins, C. Genomic content and new insights on the origin of the B chromosome of the cichlid fish Astatotilapia latifasciata. Genetica 2011, 139, 1273-1282. [CrossRef] [PubMed]

91. Green, D.M. Muller's Ratchet and the evolution of supernumerary chromosomes. Genome 1990, 33, 818-824. [CrossRef]

92. Magoon, M.L.; Shambulingappa, K.G. Karyomorphology of Sorghum propinquum and its bearing on the origin of 40-chromosome sorghum. Chromosoma 1961, 12, 460-465. [CrossRef]

93. Barnaud, A.; Deu, M.; Garine, E.; Chantereau, J.; Bolteu, J.; Koïda, E.O.; McKey, D.; Joly, H.I. A weed-crop complex in sorghum: The dynamics of genetic diversity in a traditional farming system. Am. J. Bot. 2009, 96, 1869-1879. [CrossRef]

94. Sagnard, F.; Deu, M.; Dembélé, D.; Leblois, R.; Touré, L.; Diakité, M.; Calatayud, C.; Vaksmann, M.; Bouchet, S.; Mallé, Y.; et al. Genetic diversity, structure, gene flow and evolutionary relationships within the Sorghum bicolor wild-weedy-crop complex in a western African region. Theor. Appl. Genet. 2011, 123, 1231. [CrossRef] [PubMed]

95. Sapre, A.B.; Deshpande, D.S. Origin of B chromosomes in Coix L. through spontaneous interspecific hybridization. J. Hered. 1987, 78, 191-196. [CrossRef]

96. Schartl, M.; Nanda, I.; Schlupp, I.; Wilde, B.; Epplen, J.T.; Schmid, M.; Parzefall, J. Incorporation of subgenomic amounts of DNA as compensation for mutational load in a gynogenetic fish. Nature 1995, 373, 68-71. [CrossRef]

97. Perfectti, F.; Werren, J.H. The interspecific origin of B chromosomes: Experimental evidence. Evolution 2001, 55, 1069-1073. [CrossRef] 